\title{
Dispositif Analysis in Eastern Europe: The Outline of a Research Program
}

\author{
Magdalena Nowicka-Franczak
}

University of Lodz

DOI: http://dx.doi.org/10.18778/1733-8069.16.4.08

\section{Keywords:}

dispositif analysis,

Eastern Europe, interdisciplinarity, neoliberalism, Poland

\begin{abstract}
The article discusses uses of dispositif analysis inspired by Michel Foucault's late works, in a context different from the original one. The author presents the main methodological assumptions of dispositif analysis and the factors which result in its critical and interdisciplinary potential not being fully exploited at present. Based on a literature review of dispositif analysis in post-socialist Eastern Europe, the author formulates an interdisciplinary research program aimed at adapting this approach to the study of East European power networks, taking into account both its different historical, cultural, and geopolitical context - compared to the one of West European countries - and Foucault's conception of neoliberalism. Methodological recommendations are presented in two research areas: 1) labor in the Polish post-transformation society; and 2) reactions to pedophilia in the Polish Catholic Church.
\end{abstract}

\begin{abstract}
Magdalena Nowicka-Franczak is an Assistant Professor at the Department of Research on Social Communication, University of Lodz. Her academic interests focus on the public debate in Central and Eastern Europe, collective memory of Shoah and WWII, post-Foucauldian discourse analysis, and postcolonial studies. Her book, titled Niechciana debata. Spór o ksiażki Jana Tomasza Grossa [Unwanted Debate: A Dispute on the Books by Jan Tomasz Gross] (2017), won Stanislaw Ossowski Prize of the Polish Sociological Association.
\end{abstract}

\section{Contact details:}

Zakład Badań Komunikacji Społecznej

Katedra Socjologii Kultury

Instytut Socjologii

Wydział Ekonomiczno-Socjologiczny

Uniwersytet Łódzki

ul. Rewolucji 1905 r. 41/43

90-214 Łódź

e-mail: m.nowicka_franczak@uni.lodz.pl 


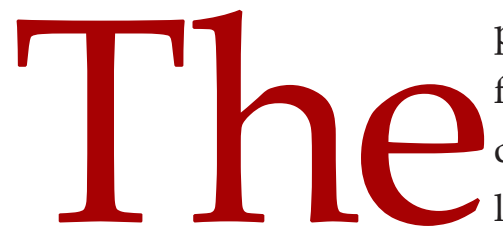

point of departure for this article is Michel Foucault's singular statement - a note which he wrote about himself, published in the Dictionnaire des philosophes under the pen-name Maurice Florence. He writes that the leitmotiv of his analyses is "a systematic skepticism about all anthropological universals" (Florence 1988:14). Then, he enumerates three methodological principles. First, one should "avoid as much as possible the universals of anthropology (...) in order to investigate their historical constitution" (Florence 1988:15). Second, instead of ascending toward the object of knowledge, "we must descend to the study of the concrete practices through which the subject is constituted within a field of knowledge." Third, one needs to "address "practices « as the domain of analysis, and to take up the study in terms of what »we do «" (Florence 1988:15).

The purpose of the argument herein is an attempt at translating the above-mentioned principles into scientific tools for a researcher of discourse and dispositif who analyzes power relations in post-socialist Eastern Europe. This researcher uses the approach of post-Foucauldian ${ }^{1}$ dispositif analysis in a context different from the original one. Besides reflecting on the historical background of this empirical study area, the researcher should take into consideration the existing criticism of the Foucauldian perspective, regarding, among other things, Foucault's attitude toward neoliberalism and its implications for analyses of contemporary power relations inspired by this author (e.g., Zamora and Behrent 2016; Dean 2018). In order to use the dispositif

${ }^{1}$ Using the term post-Foucauldian, I refer to the applications of Michel Foucault's theory in empirical research not undertaken by Foucault himself. approach in an appropriate way, one should subject the very category of the dispositif to a critical test, as well as scrutinize the related notions, such as governmentality, by looking at them through the prism of local power networks.

The first part of this article concerns the sources of the category of the dispositif and the main assumptions of dispositif analysis as a research program. It discusses the critical and interdisciplinary potential of this approach and the factors which block it. In the second part, I offer a proposition for adapting the dispositif approach to a more localized field of research. I present an outline of an interdisciplinary program for studying the relations of power, knowledge, truth, and the subject in East European post-socialist states. The frames of this approach are delineated with the use of two examples of areas from the Polish context, concerning 1) labor in a post-transformation society (research on forms of post-socialist neoliberal rationality) and 2) reactions to scandals connected to pedophilia in the Polish Catholic Church (research on the forms of local post-traditional morality actualized in liberal democracy).

\section{Dispositif Analysis: Its Sources and Development}

In the perspective of the two decades which have passed since the first attempts at a crystallization and operationalization of Foucault's notion of the dispositif in empirical research (e.g., Keller 1998; Cruikshank 1999; Peeters and Charlier 1999), one can look at the dispositif approach lightly skeptically as at a kind of methodological dispositif, whose function is "that of responding to an urgent need" (Foucault 1980:195), in which discourse analysis has found itself. Although discourse analysis should be 
regarded, especially epistemically, as an interdisciplinary perspective, on the theoretical and methodical level its practical applications usually appear to be rather multidisciplinary, with the dominance of linguistic research tools (cf. Czyżewski et al. 2017:913). This is because at the turn of the century one could more and more often hear the postulate that discourse analysis should depart from just analyzing text as a product of practices and social norms toward analyzing the whole process of production of discourse as well as its material determinants and communication practices as such.

Dispositif analysis - first treated as a supplement to discourse analysis, and later as an independent method which had grown out of Foucault's theory of discourse and power - was an answer to the domination of the linguistic perspective in research on discourse (especially visible in continental Europe) and an attempt at "socializing" it by giving up on isolating discourse from the nexus of relations between legal, political, economic, educational, and cultural institutions (including religious ones) as well as those connected to the production of knowledge. This attempt was undertaken first by researchers belonging to linguistic and pragmatic traditions, who were using the achievements of these disciplines in a critical way. Soon they were joined by sociologists, political scientists, and educationalists. However, they were all still facing the main problem of post-structuralist studies of discourse: on the basis of quantitatively limited empirical (usually textual) material, which is fragmentary and characteristic only of a given discourse, one not only draws conclusions about the properties of discourse as a whole, but also frames these conclusions as theoretical categories which become a part of scientific meta-discourse and a reference point for studying other fragments of discourse.
The main methodological issue lies in the questions about, as Johannes Angermuller (2010:77-78) puts it, "how to pass from formulating problems concerning research material, characteristic for the scientific discourse or meta-discourse, to object-centered discourse? What should be the transition between the "micro" and "macro « levels of object-centered discourse, and how to reintroduce the theory of object-centered discourse into scientific meta-discourse?"

The answer to this question is to make the dispositif in the particular meaning given to it by Foucault, i.e. a meta-category of studying power relations in a society. In Foucault's works, the dispositif is not precisely defined. In general, it refers to the network of strategic relations connecting different kinds of social discourses, institutions, architectural, legal, and administrative solutions, as well as scientific knowledge, social philosophy, and ethics (Foucault 1980:194). The dispositif, though it points to the complexity of the production process of discourse, serves as an initiator of "sense reduction processes" (Angermuller 2010:90) and dilutes discourse through excluding many possible meanings and interpretations or through delegitimizing them as being untrue or immoral. The dispositif's task is to explain and neutralize sudden situations which threaten the political, economic, cultural, or populational status quo by means of such a reorganization of the discursive and non-discursive order which would put an end to a crisis or limit the risk of turbulence. A non-discursive order functions owing to non-discursive practices (material artifacts, institutional procedures, routine non-verbal actions, etc.), which can be performed and valid without their discursive representation; however, they are usually accompanied by discursive practices of enunciation. 
The dispositif should be understood as a mechanism of dispersed power and a tool for governing people according to both historical and contemporary forms of governing. Based on Foucault's texts, one may differentiate between three types of the dispositif of power: legal dispositif, i.e. the system of prohibitions and sanctions connected to sovereign power; disciplinary dispositif connected to disciplinary power, which forces individuals to behave according to a system of norms; and the dispositif of security, corresponding with the (neo) liberal governmentality (rationality of power), according to which individuals become both subjects and objects of power, and are supposed to discipline themselves, implementing in their lives optimal or at least average models of conducting themselves (Raffnsøe, Gudmand-Høyer, and Thaning 2011; 2016). Dispositif analysis usually refers to the latter type, perceiving it as a tool of neoliberal power, promoting the model of a resourceful citizen, responsible for themselves and their role in society (Bührmann 2004). Actors of "governmental" social reality are not seen as autonomic producers of discourse, but as products of discursive power relations who generate discourse. One can compare them to prosumers consuming contents, practices, and artifacts in the capitalist economic and media system, and, as a result, producing other contents, practices, and artifacts (Ritzer and Jurgenson 2010). Dispositif analysis assumes that the dispositif is a system that is able to be identified empirically (Bührmann and Schneider 2008:152) owing to the abductive analysis of connections between the orders of knowledge, orders of discourse, and their materializations within the broad field of social practice. The research program includes synchronic and diachronic analysis of relations between the components of the dispositif and a genealogical reflection on the sources and changes determining power relations. Dispositif analysis poses not only questions about the relationship between discourse and non-discursive levels of reality, but also one about relations between orders of knowledge and a different social genesis (Jäger 2012:113-115). To sum up, for dispositif analysis, discourse serves as a crucial empirical category. Still, as an element of a theoretical model of power relations, discourse is essential no less and no more than other elements of the apparatus.

The research style of dispositif analysis is based on two pillars: 1) reconstructing the orders of knowledge on the basis of discursive utterances, 2) observing non-discursive elements and determinants of the studied problem, such as social practices, institutional solutions, material and architectural infrastructure, and cultural symbolism. What is highlighted is studying non-discursive practices as complementary mechanisms or even as mechanisms preceding the production of discursive utterances. Reiner Keller (2005:250-252) distinguishes between 1) discursive and non-discursive practices of (re)producing discourse (customary discursive formulas or culturally determined reactions to discursive utterances, e.g. a handshake, or crossing oneself), 2) discourse-generated model practices (e.g. a doctor formulating their diagnosis according to a given schema or people sorting waste according to an administrative regulation), 3) extra-discursive practices, or customs and routines independent from discourse (e.g. eating and personal hygiene), including verbalized ones (such as occasional small talk).

The main reference point for scholars using dispositif analysis is the research program of Andrea Bührmann and Werner Schneider (2008). These authors define the dispositif as an empirically palpable mechanism for solving social problems, in which 
dispersed and anonymous power is expressed (Foucault 2000). For the sake of empirical research they operationalize this category as a dynamic set of relations between discursive formations (specialist, colloquial, etc.), non-discursive practices (e.g. institutional ones), symbolic and material objectivations (e.g. statues, paintings, buildings, objects of everyday use, social rituals, etc.), and ways of forming/positioning subjectivity, resulting in specific types of subjects, optimal from the perspective of the rationality of power (Bührmann and Schneider 2008:94-96).

Abduction serves here as the main logic of reasoning, which enables drawing the research conclusions. The applied form of abductive reasoning follows a post-structural premise that formulating a hypothesis constitutes a fundamental rule of intellectual consideration (Eco, Sebeok 1984). Apart from pure logical reasoning, abduction needs the observation of the external reality. It allows us to infer dispositif's characteristics however it is conceptualized, i.e. as a theoretical model of power relations or as an empirical set of interdependencies materialized in social practice. The first step in the research procedure is diagnosing the social changes and groundbreaking situations activating the dispositif. The second stage is "reconstructing the dispositival construction of reality" (Bührmann and Schneider 2008:85) on the basis of empirical material collected and analyzed through interpretative approaches (e.g. biographical methods, in-depth interviews, focus group interviews, observation, sequential analysis of everyday communication, historical-critical analysis of social implementations of artifacts), the meta-language of which comprises the instruments of the Foucauldian discourse analysis (Diaz-Bone 2007). The third step is diagnosing the intended and unintended consequences of power relations, including the effects of interactions between institutional orders of knowledge and the realm of praxis and an unscientific understanding of the world (Bührmann and Schneider 2008:52-55). By positioning the subject within discourse and the forms of subjectification of individuals in everyday life, the researcher abstracts the "social self": the kind of practice in which subjects are constituted through social relations, handling objects, and experience (Bührmann and Schneider 2008:32-33, 69).

When discussing the research program of dispositif analysis, one should stress the fact that in research practice it undergoes modifications depending on the area of social reality that is subject to the post-Foucauldian empirical analysis. For example, Sverre Raffnsøe, Marius Gudmand-Høyer, and Morten S. Thaning (2016) propose using the socalled dispositional analysis (a variation of dispositif analysis) within the field of organizational research, stressing that one should analyze different types of organizations as dynamic organisms which do not subject themselves to epochal periodization, acting in a way that never is completely determined. Dispositional analysis takes the pragmatic shape of "an affirmative critique," which does not point to what the organization does wrong, but which shows why the organization can work the way it does and what system of relations is thus produced.

In turn, in critical educational research, dispositif analysis highlights the simultaneous work of different kinds of dispositifs. Helena Ostrowicka (2015:129) calls the interrelation between these mechanism the "apparatus diagram" (after Gilles Deleuze), which for educational studies "becomes a research perspective in analyzing specific dispositifs, which in different configurations unite disciplinary mechanisms, mechanisms of law and 
of security with the rationalities and forms of subjectification (»subject formation«) which legitimize them," i.e. key tasks of educational practices. Dispositif analysis, together with its zonal variants, is a research program in light of which the critical and meta-critical reflection on the dynamics and morphology of social power relations should be practiced within a specific though possibly incomplete fragment of social reality. Achieving the ambitions of this program requires openness to the interdisciplinarity of research, understood, however, not as an institutional obligation in the contemporary academia, but as a methodological and intellectual challenge.

\section{The Interdisciplinary Potential of Dispositif Analysis and Its Limitations}

In 1967, Paolo Caruso asked Foucault directly in an interview: "To which discipline do you think your research belongs?" (Foucault and Caruso 1999:91). Caruso was determined to obtain a clear declaration. However, Foucault did not give him this satisfaction:

It is hard for me to classify a form of research like my own within philosophy or within the human sciences. I could define it as an analysis of the cultural facts characterising our culture. In that sense, it would be a question of something like an ethnology of the culture to which we belong. I do in fact seek to place myself outside the culture to which we belong, to analyse its formal conditions in order to make a critique of it, not in the sense of reducing its values, but in order to see how it was actually constituted. [In addition, through analysing the very conditions of our rationality, I call into question our language, my language, and analyse the way it was suddenly able to emerge]. (p. 91)
Taking Foucault's words at face value, one could call his strategy trans- and meta-disciplinarity. It is trans-disciplinarity, because his analysis is intended to transgress disciplinary ways of understanding power and go beyond culturally grounded practices of producing scientific truth. It is meta-disciplinarity, because its purpose is the study of the conditions of those possibilities that underlie the facts of culture which are the main subject of humanistic and sociological reflection. The object and tool of such research is social language, the language of the existing social analysis, and the researcher's own language. Foucault does not distance himself from the methodology of a philosopher, historian, historian of ideas, linguist, sociologist, or psychoanalyst. Although he is at times closer to multi-disciplinarity (putting together approaches stemming from different disciplines) than to interdisciplinarity, his works are grounded in many critical strands of humanities and social sciences.

I propose looking at dispositif analysis inspired by Foucault's words as at an interdisciplinary approach par excellence and, at the same time, a trans-, meta-, and multi-disciplinary one. By interdisciplinarity, I understand here a thoughtful encounter of different disciplinary perspectives. The encounter is based on the attempts to critically analyze, synthesize, and harmonize relations between the disciplines and work out a coordinated and coherent research approach. The trans-disciplinary approach refers to going beyond the existing frames of disciplines in order to offer a revision of well-known concepts. Meta-disciplinarity means that researchers maintain a critical awareness of the boundaries of the disciplines they refer to - and problematize - these limitations already in their studies' outline. In contrast, multi-disciplinarity relates to heterogeneous research devices without transcending the 
boundaries of disciplines (see, e.g., Choi and Pak 2006:359; Schmidt 2008; Alvargonzález 2011:387-389). Interdisciplinarity can serve as an umbrella term for all these aspects; however, the differences between them should be kept.

While discussing the interdisciplinary potential of dispositif analysis, one should distinguish between its epistemic and theoretical-methodical dimensions. Epistemically, dispositif analysis is interdisciplinary, because its object of interest is defined in a dialogue of different disciplinary ontologies. Simultaneously, the theoretical-methodical dimension of the interdisciplinary potential is linked to the core of the research practice. First, it is based on the postulate of studying different cultural facts (discursive, material, symbolic, and ethical ones) which should be extracted and analyzed with multi-perspectival methodological instruments. Second, the interconnection between the elements of the dispositif is analyzed as a linguistic and psychological operation, as a game within a specific political economy, or as a political and institutional rationality. One may see in dispositif analysis an interdisciplinary method, because it requires a critical dialogue between approaches to empirical reality that have their sources in different disciplines. Triangulation through a number of methods of analyzing text, practices, and processes is, in a way, inscribed in the basic assumptions of dispositif analysis as a research style. However, through the observation of research practice one might reach the conclusion that only a small fraction of empirical dispositif analyses is truly interdisciplinary. They usually remain disciplinary, only postulating the transgression of the boundaries of linguistics. This issue will be discussed with reference to selected analyses carried out in the German and the Polish contexts. The community of German dispositif re- searchers is the most advanced methodologically and, perhaps, the most numerous. In comparison, Polish dispositif researchers are a small group, on the one hand strongly inspired by the German authors, and on the other hand experimenting with the method of dispositif analysis. Nevertheless, in both the German and the Polish case the potential of interdisciplinarity is used to a limited extent.

The methodological and technical difficulties which limit the interdisciplinary character of dispositif analysis include at least three issues. The first of these is connected to the patterns of conceptualization and operationalization of the Foucauldian notions. In Germany, the most popular reference point is the above-mentioned approach developed by Bührmann and Schneider (2008), in which using the notion of the dispositif means adopting a research perspective in which non-discursive practices are not autonomic but are a result of the work of discourse and orders of knowledge which are its foundation. This path is followed e.g. by Brita Hoffarth (2013) and Nadine Rose (2013), who treat dispositif analysis as an opportunity to ground discourse in material reality and to demonstrate the interdependence of discursive and non-discursive practices, with the former one playing a superordinate role. In turn, Norbert Ricken (2015), speaking of educational dispositif, poses the question of the genealogy of intellectual discourse from which contemporary educational institutions might have emerged. A Polish researcher Helena Ostrowicka (2019:28) approaches the problem in a similar way, calling her approach Dispositif Discourse Analysis and stressing that "dispositif analytical strategy assumes a circular relationship between discourse and the dispositif, with the latter operating only in conditions of the discursivization of a problem, while generating and processing it at the same time." Discourse and 
discursivization are here necessary conditions for the emergence in social awareness of a state of urgency which would activate dispositif mechanisms. Marek Czyżewski (2012), referring to the example of the dispositif of the "society of knowledge," writes that it consists of two pairs of elements: the first one being scientific discourses and institutions, and the second - discourses within business and organizational practices and institutions in the field of practice (businesses, government branches, local government institutions, social assistance, and psychotherapy). In this approach, the dispositif also includes disciplines such as psychology, social care, education, and major parts of sociology. Therefore, different types of discourse are conceptualized as the key components of the dispositif.

The second limitation in making dispositif analysis more interdisciplinary stems from the practices of constructing the corpus of empirical materials. Despite declaring that the researchers' objects of interest are both discursive and non-discursive practices, the former take precedence, whereas knowledge about the latter is usually only derived from the analyzed discourse. For example, Imke Niediek (2010), when researching individual programs of social assistance aimed at persons with intellectual disabilities, studies written documentation of assistance institutions and experts' statements, i.e. the discursive representation of the research's object. Similarly, Ostrowicka (2016), studying dispositif programs that encourage scientists to collaborate with business, bases her research on institutional documents and not on observing the practices of implementing these programs. In the context of studies on academic dispositifs, an interesting proposition is offered by Jens Maesse (2017), who suggests studying what he calls academic elitism dispositif through analyzing the rankings of academic journals and the concentration of academic capital in the hands of large academic entities. Maesse combines the post-Foucauldian perspective with Bourdieuan and centroperipheral ones. This, however, works to the disadvantage of the depth of discourse analysis, which is reduced to generalized remarks on the logic behind constructing the analyzed rankings. One of the few examples of a corpus which is both discursive and non-discursive can be found in Łukasz Kumiegga's research (2013) on German right-wing extremism, where artifacts used during public demonstrations of the radical right are studied along with discursive utterances. One needs to remember that only through constructing a hybrid corpus is the researcher encouraged to look for interdisciplinary inspirations.

The third, problem is the asymmetrical combination of discourse analysis with other methods of qualitative and quantitative research. Since dispositif analysis is usually treated as enriching discourse analysis with a reflection on the practices and institutions connected with the text (Keller 2007), the triangulation to which researchers subject their materials usually requires combining several hermeneutic methods under the umbrella of grounded theory methodology, as is the case with the work of Inga Truschkat (2008), or extending the textual study of discourse to include visual analysis, as in the case of Hermann Mitterhofer (2016), or elements of interactional qualitative research (Nowicka-Franczak 2017). What stands out against this background is a proposition for intersectional dispositif analysis by Stefan Paulus (2015), which consists in studying three levels of the dispositif's operation: structural, symbolic, and subjective, by combining methods derived from economy, political science, linguistics, and semiotics. However, Paulus's practical methodology concentrates on critical discourse analysis, while the institutional level of the dispositif is 
described rather than analyzed, and the empirical materials for the subjective level consist mostly of free interviews. Thus, one can see in the program of intersectional dispositif analysis a clear domination of linguistic and sociological methods.

It is even less frequent for researchers to decide to use quantitative methods in dispositif analysis. A study worth mentioning is the analysis of research interests declared on websites by the UK full professors in sociology within the context of biographic and institutional determinants (Hamann et al. 2019). The point of departure is not only the combining of the methods of linguistic text analysis with sociological methods and techniques (questionnaires, interviews, statistical and ethnographic analyses), but also the Foucauldian perspective with the Bourdieuan field theory. Analyzing the academic dispositif relies upon a context-centered analysis of academic discourse, carried out with qualitative and quantitative methods (e.g. correspondence analysis) in order to map the position of the participants of a researched discursive formation, taking into account the synchronic and diachronic biographical and institutional context. Owing to the statistical method of studying lexical and syntactic correspondences, the researchers have worked out maps of the relations between the research interests of professors of sociology, their affiliations, academic careers, and professional networks, and have observed trends in trans-disciplinary changes in the field of academic sociology. This is how the category of the dispositif has been operationalized "in order to seize the social context as an institutional arrangement of linguistic practices and non-linguistic practices, rules, and structures in a larger social community" (Hamann et al. 2019:54), and dispositif analysis as a researching language in the broad context of its production (Hamann et al. 2019:53).

\section{Post-Socialist Eastern Europe as an Area of Research}

Whether researchers of the dispositif are open to interdisciplinary tools and the triangulation of methods or not, they tacitly assume that the conception of the dispositif can correspond with the studied power relations regardless of the local context in which they function. Can, however, the dispositif belong to a universal meta-language of power analytics, and can dispositif analysis be used in the same way regardless of the physical and symbolic localization of the fragment of social reality it is critically applied to? These questions should be posed in the case of specific, local applications of dispositif analysis. The case discussed below refers to empirical analyses of power relations in those East European countries which for many decades remained within the sphere of influence of the Soviet Union, or even constituted a part of it, and today are democratic republics with free market economies as well as they are members of the $\mathrm{EU}^{2}$. It is a case deserving critical reflection for at least two reasons: because of the dynamics, unique in Europe, of changes in the forms of power in these societies, determined by the conditions at the end of the socialist planned economy and the period of transformation at the turn of the 1990s, and because of the singular dynamics of

\footnotetext{
${ }^{2}$ Post-socialist countries also include states which came into existence after the breakup of the Socialist Federal Republic of Yugoslavia. They have not been taken into account here, because this region was relatively independent from the Soviet Union in comparison to Eastern Europe, and the Balkans' passage to the post-socialist stage has been marked with the trauma of a civil war. This is why not all remarks concerning the historical and political context of carrying out dispositif analysis in Eastern Europe formulated in this article refer adequately to the countries of former Yugoslavia. Of course, dispositif analysis has been practiced by researchers of this region (e.g., Pezelj 2015; Mraović 2018). There are also dispositif analyses referring to the former Soviet Republics which have introduced a democratic system but are not part of the EU, such as Georgia (Ditrych 2011).
} 
applying the Foucauldian approach to analyses of changes in forms of power in this region.

Interest in this methodological perspective appeared in Eastern Europe approximately ten years after its first uses in Germany and the Anglosphere. It would, however, be difficult to call dispositif analysis a popular approach among qualitative researchers from Eastern Europe, or even those analyzing this region. This limited interest probably stems partly from the fact that, in its presently dominant form, this approach is not sufficiently adapted to empirical research of the social reality in countries of this region, where the subject of research is post-socialist society and institutions.

The approach of dispositif analysis is sometimes used in studying phenomena occurring in Eastern Europe but not specific to this region; instead, it is connected to the global trends in the spheres of economy, politics, communication, and technological development. These analyses are usually carried out at a very general level and offer vital but broad conclusions concerning the empirical reality. Possible local variants of the studied phenomena are rarely problematized in these analyses: their cognitive value lies in indicating common areas on the global map of institutions of power: administrative and educational ones or those producing scientific and practical knowledge (e.g., Czyżewski 2012; Ditrych 2014; Chutorański 2015; Ostrowicka 2016; 2019). What is more, dispositif analysis has been used in research on the phenomena adopted from Western societies and transferred, with varied results, to Eastern Europe. Analyses of this kind attempt to demonstrate the specificity of East European dispositifs of power in organizing key areas of social life - such as political campaigns, the healthcare, or education system - by directly applying the Fou- cauldian categories and those taken from Western post-Foucauldian studies for the purposes of empirical research. These analyses point to local varieties of forms of the rationality of power and its discursive and non-discursive tools, but usually do not problematize the Foucauldian conceptual tools (e.g., Toader 2014; 2017). A worth-mentioning exception is a study by Helena Ostrowicka, Justyna Spychalska-Stasiak, and Łukasz Stankiewicz (2020), in which the authors problematize - in the context of the Polish higher education policy - the Foucauldian notions of juridical, disciplinary, and neoliberal power as well as their hybrid variants by confronting them with the approach of Reinhart Koselleck's historical semantics and Bob Jessop's concepts of crisis and public debate. Finally, dispositif analysis has been used in research on problems specific to particular societies of the region in question (e.g., the public debate on wartime Polish-Jewish relations [Nowicka-Franczak 2017]; the situation of the Romani minority in the Czech Republic [Hušek and Tvrdá 2016]; the social construction of the Slovak identity [Profant 2018]; the heritage of the socialist model of the family in Bulgaria [Lyubenova 2017]). However, these studies also lack in-depth reflection on adjusting the approach to research on the post-socialist countries of Eastern Europe.

In the article herein, I use the term 'post-socialist' rather than 'post-communist' in relation to the contemporary situation of East European countries. This choice has been dictated by the fact that although all those countries called the Eastern Bloc before the year 1989 experienced the communist regime, in each of them it had different intensity and dynamics. In some, such as in Poland, communism in the narrow sense (as a coherent political and economic doctrine) functioned until 1956, and afterwards transformed into an authoritarian system 
with an eroding socialist economy. In others, communist governments subordinate to Moscow functioned until the breakup of the Soviet Union in the early 1990s. At the same time, though, all of those countries experienced the doctrine of real socialism, connected to a centrally planned economy and political control of consumption and manifestations of entrepreneurship, which led to the situation of the so-called "shortage economy" as a result of it not fulfilling society's needs and material aspirations (Kornai 1980; Gomułka 1985). The inefficiency of the socialist economy is believed by many economists and sociologists to be the deciding factor in the fall of the regimes of the Eastern Bloc (e.g., Kovacs 1992; Wnuk-Lipiński 1996; Eyal, Szelenyi, and Townsley 2001; Bugaj 2015).

There is a multifaceted critique of the category of post-socialism as a historicism which does not "get" the pace and diversification of the direction of changes which took place in the East European countries as a result of their political transformation, and is a derivative of Western social and economic thought: a notion which a priori assesses the economies of the countries of this region as being weaker and less developed in comparison to the system functioning in the West (Thelen 2011; Kideckel 2014; Lubaś 2017). Despite acknowledging the existence of this critique, I still chose the category of post-socialism because of its ambiguity, which is interesting from a sociologist's point of view. On the one hand, it describes a historically determined objective difference in the materially measured standard of living between countries of Eastern and Western Europe. On the other hand, this category refers both to the postulates of modernization and to the identity and dignity of East Europeans. Speaking of the post-socialist condition can mean situating a given socioeconomic system within the global configura- tion of capitalist forces, but also the position of individual subjects living in this system vis-a-vis its other elements and external subjects. This is why the category of post-socialism resonates with critical reflection concerning the different levels of social power, its present forms, their historical sources and prefigurations.

Such a reflection should not settle for a direct application of the Foucauldian terms and categories for studying the local reality, but should take into consideration a number of factors which differentiate the situations of East European societies: 1) the historical and political determinants of phenomena occurring in post-socialist countries; 2) a diagnosis of contemporary forms of capitalism and consumerism in the context of the cultural and symbolic sphere of these societies; 3) the imitative, hybrid, or competitive character of local institutional solutions with regard to Western social systems; and 4) the modernizing and dignity-building function of local discursive and non-discursive practices in the context of the tension between the Western Center and Eastern Peripheries of Europe.

\section{The Program of 'East European' Dispositif Analysis}

The following research program of dispositif analysis carried out in the context of post-socialist forms of governing society refers very loosely and modestly to the conceptions of the research programs by Imre Lakatos (1968; 1999). This program is intended to serve the researcher as a heuristic guidepost in designing empirical research; it is not, however, a coherent system of terms or a complete collection of methodological rules. Rather, it is an open list of methodological suggestions aimed at a theoretical framing and empirical testing of the 
post-Foucauldian approach within the area of East European issues, completed with methodological and conceptual approaches taken from different disciplines. The following program consists of four recommendations, presented in an order which is not accidental. They are an attempt at formulating a positive answer to Foucault's postulates quoted at the beginning of this article, concerning skepticism towards anthropological universals and to studying phenomena in their historical construction and through reflecting on the practices in which the subjects of these phenomena are constituted. The aim of this program is a critical confrontation with the processes of sedimentation, i.e. the perpetuation of discourse (it is a notion used in discourse analyses inspired by Ernest Laclau's theory, e.g. in post-foundational discourse analysis [Marttila 2015]) and treating it as something obvious and self-evident. Such a confrontation consists in uncovering the historical sources of discourse, reminding one of the contingency and a lack of objective necessity for the occurrence of particular discursive forms, and in de-constructing the material surroundings of the discourse, i.e. practices, artifacts, and institutional procedures which accompany it and whose role is to naturalize meanings produced in the discourse.

\section{Recommendation 1: Avoiding discursive absolut-} ism. When planning research on the post-socialist art of government, the first step should be acceptance of the fact that studying discourse alone is not enough to make Foucault's perspective a basis for empirical research in this area. In countries which have gone through a technocratic political and economic transformation, the discourse not only projects a certain shape of social reality, but it also justifies the ineffectiveness of its realization in some spheres of life. Discourse plays here a double role of both the explanans and the explanandum, and these two roles are easily identified with each other, which may suggest to the researcher an erroneous image of the discourse's character and scope of power. Therefore, as early as at the initial stage, one should ask questions on the strategic functions which can be performed by the analyzed discourse in the situation of material, ideational, and temporal incongruity between its resources and the non-discursive reality which it refers to. At the stage of constructing the corpus of empirical materials, one should ensure that both discursive and non-discursive materials can be a tool for testing each other's validity. For example, if one wants to study the dispositif of innovation as a political tool of East European modernization, they should take into account - along with prescriptive fragments of discourse on the imperative of innovation of peripheral societies - the procedures of practically determining the innovativeness of ideas, objects, and services, and their relative market and symbolic value in comparison to what is believed to be innovative in the West, where the intellectual and social affirmation of innovativeness was born (see: Zarycki 2014).

\section{Recommendation 2: Interdisciplinary diagnosis} of the type of rationality of power and the condition of the governed population. Dispositif analysis is a study of power relations occurring on macro-, mezzo-, and micro-social levels and validated in intellectual, scientific, and political discourse through referencing specific techniques used by the government and political economy. The category of the dispositif is developed in Foucault's late works - especially in his Collège de France lectures (Foucault 2008) - on governmentality understood as neoliberal rationality. This is probably why the majority of post-Foucauldian empirical dispositif analyses concern the dispositifs of security connected to neoliberal governmentality. Using these categories 
in the case of East European countries requires the determination of the type of rationality of power one is dealing with in a given local context. Foucault wrote mainly (and partly affirmatively) on German ordoliberalism and early forms of American and French neoliberalism. His followers use the notions of neoliberal governmentality and the dispositif of security for critical research on contemporary forms of neoliberal capitalism, emerging after the socalled Washington Consensus.

The situation in post-socialist Eastern Europe is quite different. Although some countries of the region, such as Poland or Estonia, are perceived as leaders of neoliberal trends in the economy and social organization, we have here a unique and non-linear process: a rapid implementation of neoliberal technology by government on top of the vestiges of an inefficient socialist system. Such a case could not, for historical reasons, have been taken into account by Foucault (and was not considered by him even hypothetically); and neither is it developed more broadly in the works of post-Foucauldian researchers. However, the question about the adequacy of the conception of neoliberal governmentality and its strategic tool (the dispositif of security for studies of a post-socialist, hybrid set of power relations) is an important issue, protecting us against the trap of an erroneous reasoning which would project the conclusions accepted in Western (post)Foucauldian analyses onto the East European context (Nowicka-Franczak in print) ${ }^{3}$. Attempting to answer this question should be one of the first stages of dispositif analysis carried out in the area of post-socialist power relations, or at least consti-

\footnotetext{
${ }^{3}$ A similar problem concerns the concepts of juridical power and discipline: their conceptualization and application in the post-socialist reality should include reflecting on its hybrid character linked to the entanglement of socialist legacy, pro-Western imitation, and anti-Western counter-ontology.
}

tute one of the research problems which would not have the character and effect of a pre-assumption, but would be subject to theoretical and empirical testing in the process of analysis.

In order to realize this goal, one needs to include in the analysis of the post-socialist dispositif of power some elements of economic, political, and macro-sociological analysis. Foucault overlooked this, but he analyzed the rationalities of government which emerged historically from the changes in West European states and economies, and that were not imitative and technocratically implemented on the ruins of a former socialist regime. The interdisciplinary diagnosing of the type or types of the post-socialist rationality of government allows one to bring order to the main tactics and practices of neoliberal power occurring in the researched fragment of social reality, while also estimating the scope of their effect.

This is why, despite the reluctance of human scientists and qualitative sociologists, it is worth taking into consideration macro- and microeconomic - as well as macro- and micro-social - indicators and indexes connected to the state of democracy (the standings for East European countries in comparison to those reached by West European states), such as, inter alia, GDP, GDP per capita, Human Development Index, Balanced Development Index, GINI index, World Income Distribution, unemployment rate, labor force, the level of public debt and external debt, Global Innovation Index, Corruption Perceptions Index, Freedom in the World reports (Freedom House), Distributional National Accounts (Blanchet, Chancel, and Gethin 2019), Democracy Index, as well as the World Values Survey, Satisfaction with Life Index, Where-to-be-born Index, and the Happy Planet Index. This list is not complete and needs to be constantly modified, depending on the specific 
object of research. What is more, these indicators, despite being broadly considered to be objective measures, are based on arbitrary premises and do not show the real divisions of power in the world, but, rather, their explanation. One should not see them as the answer to the question on the efficiency of the analyzed power configurations, but instead use them in order to define where in the European or global network of political and economic interdependencies and their social assessment post-socialist countries are situated in light of the dominant forms of presenting these interdependencies.

\section{Recommendation 3: Modernization- and digni- ty-related aspects of post-socialist dispositifs. The} use of dispositif analysis for the study of East European societies is following fashionable trends in critical studies of power and a way of intellectual catching up with the West. The awareness of this dependency should sensitize the researcher to the way practices activated in local dispositifs function in modernizing and dignity-building. These functions concern the tension that exist between the Western Center and Eastern Peripheries of Europe, which is perceived like a student aspiring to the level of Western civilizations (see Buden 2010). These aspirations are connected both with the expectations rising from Eastern Europe's inclusion into the club of Western democracies and economies as a rightful member, and with Eastern Europe's search for its own paths of development while still preserving its cultural identity.

The tensions between the West and the East are visible twofold. First, they are revealed in the inter-societal approach, which problematizes inequalities between economically developed and democratically stable societies and the developing ones, which aspire to the idealized Western quality of democratic social life. Second, they can be seen in the intra-societal approach, which points to the inequalities between those social classes and groups that cope better in the culture of liberal values and neoliberal capitalism, and groups experiencing economic and cultural deprivation. Both these types of tensions reveal problems associated with the conflicting modernizing aspirations that are present within the public sphere: liberal and conservative ones, i.e. those directed towards a material and institutional as well as axiological pursuit of the West, or those aimed at a purposeful distancing from the West in search of a uniquely Eastern European (e.g., Polish) way of peripheral modernization (see: Krasnodębski 2003). The modernizing aspirations are confronted with dignity aspirations, directed towards affirming the cultural identities characteristic for a given post-socialist society.

An answer to these, often mutually exclusive, aspirations lies in hybrid discursive practices (i.e. practices of formulating statements), which, for different purposes, encourage selected aspects of modernization- and dignity-related claims. At the intersection of the axes of inequality, modernizing, and dignity-building functions of public discourse, I propose to differentiate between four types of discursive practices which normalize the social notions of politico-economic interdependencies and their symbolic equivalent:

1. Modernizing and (anti)Westernizing practices - these serve a modernizing function in the area of inter-societal inequalities and consist in mobilizing people to an economic, institutional, and axiological "catching up" with the West or (when they originate from the conservative right-wing ideological option) in promoting a path of modernization that is independent from the West and 
even can hold particular local traditions up as an example for Western countries;

\section{Practices connected with dignity and settling accounts} - these fulfill the function of guaranteeing/protecting one's dignity in the area of inter-societal inequalities. They consist in problematizing the symbolic and moral reparations owed by the West for the present menial international and material position of Poland (especially due to the historical events).

3. Modernizing and class practices - these serve a modernizing function in the area of intra-societal inequalities. They are characterized by mobilizing people to achieve material and cultural parity with the West through the example of the local elites (the upper class, political, artistic, media, and show-business elites).

4. Dignity and class practices - these serve a dignity-building function in the area of intra-societal inequalities. They consist in problematizing the unfair distribution of material goods and the symbolic positions within one's society (e.g. between the upper class, middle class, and the socalled 'people's class').

Determining whether and to what extent the above-mentioned discursive practices regulate the analyzed fragment of social reality is an important question when deciding which types of social crisis the dispositifs of the post-socialist art of government seek to answer. What can be of help or an inspiration for these decisions is including elements of a sociological center-periphery perspective into dispositif analysis, addressing the issue of uneven distribution of economic, social, and cultural capital within the global system and within particular societies. It is a perspective inspired by works by, inter alia, Immanuel Wallerstein (1974) and Pierre Bourdieu (1986). In the case of the latter, there is a rich theoretical dialogue between his conception and the conception of Foucault. The center-periphery perspective should be applied, however, in a version translated into the language of the particular peripheral East European power relations, as proposed e.g. by Tomasz Warczok and Tomasz Zarycki (2014). The encounter of the Foucauldian approach with the above-mentioned perspectives can lead both to the reconstruction of post-socialist dispositif as a model of the nexus of power relations in Eastern Europe, and to an analysis of different and heterogeneous aspects of social life in the region, which involve the strategic interdependence of discourse and social practices. In the second case, the distinguished four types of discursive practices should be regarded not as a fixed research template, but as a testing question to be verified based on the collected data.

\section{Recommendation 4: Avoiding textual idealism.} The proposed sociological and economic erratum to dispositif analysis performed under post-socialist conditions may not be sufficient to avoid excessive trust in the analyzed discourse, especially when it comes to its textual aspect. In other words, in order to avoid textual idealism, one should supplement the post-Foucauldian dispositif analysis by additional methodological tools. Drawing conclusions about the social reality based on texts, even the most influential ones, is especially likely to be defective in the East European context because of the imitative character of intellectual, expert, politico-economic, and media discourses with regard to the West. Discursive imitation rarely entails practices which would really work in accordance with the rationality of the analyzed discourse. The subjectivity which 
people project into it remains virtual and wishful. Minimizing textual idealism can be achieved by highlighting the symbolic function of discourse, non-discursive practices, institutions, and their procedures - both in the context of collective definitions of East European strategic positions and optimal subject models, and with reference to individual techniques of producing peripheral identities. I refer collectively to the subject of such processes as the 'practitioner of the self'. In contrast to Foucault's 'entrepreneur of the self', they are a subject fitting as much as they can into the dynamic social roles and places assigned to them in the post-socialist social system, through reinterpreting the symbolic meaning of cultural communication for the sake of the desired self-image or through everyday practices of producing, confirming, and rejecting particular models of subjectivity.

One could make use of semiology's findings on the function of language and image aimed at creating myths and normalizing the social order, as well as on the semiotic battles between the competing discourses for the status of the true source of the binding narrative on the historical and moral roots of the present social tensions (see: Barthes 1972; with reference to Poland, e.g., Wasilewski 2012; Napiórkowski 2018). What is more, it is worth considering using the methods of the so-called 'anthropology of the contemporary' (i.e. a set of techniques of observation and hermeneutic reasoning about everyday cultural practices undertaken by members of contemporary societies, but investigated within the broad context of cultural changes), political conflicts, dynamics of capitalism, and the development of scientific discourses (Sulima 2000; Rabinow and Stavrianakis 2013). One should stress that research within the anthropology of the contemporary is usually interdisciplinary, which is visible not only in its use of terms and categories from a number of humanities disciplines and social sciences, but also in the style of formulating scientific reflection, which is often literary, postmodern, and highly interpretive; not as far from Foucault's style as one might think, though less steeped in cognitive skepticism (Łuczeczko 2012).

Producing the types of subjects which are optimal from the point of view of a given rationality of power entails the necessity for both the individual and collective subjects to take a stance on the existing (though changeable over the course of the historical process) symbolic and material resources as well as local social identities which they determine by actualizing themselves at the level of both discourse and cultural practices. An interesting approach which might cast light on the spectrum of identity dilemmas and the model answers to suit them is the psychology of cultural identity. This too is largely an interdisciplinary - or at least multi-disciplinary - approach, which makes critical use of the achievements of philosophy, literary theory, sociology, cultural studies, history, psychology, and psychoanalysis. Its analyses are usually carried out within the post-structuralist paradigm. This is within a perspective close to Foucault's conception of power (although Foucault's work is not one of the main inspirations behind the psychology of cultural identity). In Poland, this type of critical reflection on the references for identity in modernity and postmodernity is practiced, inter alia, by Andrzej Leder (2014) and Piotr Augustyniak (2015; 2019).

Below, I offer concise propositions for application of these recommendations with reference to two contrastive research areas concerning power relations in the Polish society. The first area, namely labor in post-socialist capitalism, is a field of power regulat- 
ed by the political economy, influencing e.g. social divisiveness, redistribution conflicts, and the material and symbolic stratification of the Polish society. The second area, namely pedophilia in the Catholic Church in Poland (including the disclosed cases and their ensuing reactions), is a field of moral power regulated by religious doctrine, sanctioned by cultural and institutional practices, but contested nowadays by subjects from institutions of secular power. In both cases, dispositif analysis can be useful, but in a form modified with regard to the original approach.

\section{Example 1. Labor in the Polish Post- Transformation Society}

In Poland, the sphere of labor is an area which generates conflicts over whether the Polish society is, for Western economies, a reservoir of cheap and relatively ineffective labor force and a target area for outsourcing positions of lower managerial level, or whether it is a society that is achieving parity with the Western standard of living owing to the radical but successful (neo)liberal economic reforms which began in the late 1980s and early 1990s. When researching this very important sphere of social reality, one should take into consideration the rival nature of not only the discourses on labor, but also, predominantly, of the rationalities behind them. The dispositif of labor in post-socialist Poland (which in a short period of time underwent a radical change from a society almost entirely employed in positions controlled by the government to a society competing for prestigious and financially attractive posts and yet facing unemployment, income inequality, and the effects of globalization) is a reaction to the precariousness of labor, its social significance, and the connected expectations, in the form of rationalizing the actions and emotions which accompany it.
At the stage of building a corpus of empirical materials, it is worth considering expert discourses, both affirming and criticizing the existing order of labor, discourses of employers and employees rationalizing their place within this order (see: Kubala 2019), and, if possible, observing or documenting the practices of employee selection, practices of neutralizing tensions, and procedures of solving or containing conflicts in the sphere of labor. An existing pilot analysis of the collected empirical materials - supplemented by data derived from macro- and microeconomic indicators (see above) concerning the distribution of income, unemployment, professional mobility, and life satisfaction in Poland (in comparison to Western Europe) - should give one a preliminary answer to the question regarding the adequacy of the categories of neoliberal governmentality and the dispositif of security for the study of the post-socialist reality, and, thereby, direct the researcher toward the reconstruction of a hybrid neoliberal-social rationality regulating the power network in the sphere of labor. This shall then be tested and elaborated on in the process of further analysis, the purpose of which is to distinguish, on the basis of empirical materials, the above-mentioned modernizing and (anti)Westernizing practices, those connected to dignity and settling accounts, modernizing and class practices, and dignity and class. One may speculate that in the case of the area of labor, the dominating practices will be modernizing and class as well as dignity and class. Their social significance should be assessed according to the power of, on the one hand, their symbolic dimension (here semiological research tools will be useful) and, on the other hand, their common-sense and everyday dimensions (studied e.g. from the perspective of the anthropology of the contemporary). One should not forget that the peripheral position of the Polish society in the global division of labor leaves a mark 
on the identity declarations of local subjects of the labor sphere, forcing them to rationalize these choices on both the level of individual psychology and collective identifications. This is why qualitative data from interviews with employers and employees should be compared in accordance with the assumptions of the psychology of cultural identity and with Polish cultural texts concerning the sphere of labor, and would be an important supplement to the analysis of the dispositif of labor in a post-socialist society.

\section{Example 2. Pedophilia in the Catholic Church in Poland}

Although this second case is limited to a particular field, it remains closely linked to a phenomenon of juridical and symbolic power (pastoral power). It refers to a collective-national type of dispositif bondage that can also be found in other situations when a socially established institution lays claims to an exceptional moral position in a given order of discourse and knowledge. The power of the Church over the lives of individuals and whole communities is one of the main issues addressed by Foucault and can be discussed with reference to the concept of dispositif (see: Amaral 2016). The first and the fourth volumes of The History of Sexuality (1978; 2018) are particularly devoted to it. The author's interests focus on pastoral power based on the authority of spiritual leadership in the process of the self-perfecting of individuals in keeping with the doctrine and practices of revealing the truth about oneself (including public confession), formalized by the Church. The Catholic Church in Poland, which has a strong but weakening symbolic position in this country (Porter-Szücs 2011), is still interested in wielding broad moral power over the population, and the practices of confessing the truth are re- served by it for the faithful churchgoers rather than the clergy. One could speak here of a claim to pastoral power with the proviso that it is a power ritualized by tradition and legitimized not by the moral merits of the clergy but its politically, materially, and symbolically privileged position in the Polish society. The highlighting of the cases of pedophilia among the hierarchs and priests, which have for several years been publicized by the media, are an attempt at questioning this power and the Church's claims to it, although there seems little institutional and procedural support for breaking this status quo. The dispositif of reacting to pedophilia would consist in a network of discourses, social and institutional practices, legal solutions and moral doctrines, the task of which would be to neutralize any attempts to remove power from the Church, e.g. by relegating the issue of pedophilia to the problem of its victims' individual traumas.

In this case, dispositif analysis should, in order to deepen the research, open itself to reflections rooted not only in sociology, cultural studies, and religious studies, but also in psychology and media studies; by concerning itself with the genealogy of the problematizing of pedophilia in Poland and, comparatively, in other Catholic countries. The corpus of empirical materials should include data from a wide range of sources of a diverse character: media and art discourses, expert discourses, stances of the Church hierarchy, the system of justice and representatives of political power, grassroots contestation of the Church's power in the aftermath of the disclosed cases of pedophilia (local reactions, such as the pulling down of the statue of a priest accused of pedophilia, or those adopted from other countries, such as hanging children's shoes at premises belonging to the Church), as well as the ensuing reactions. Given the psychologically destructive 
character of sexual violence toward children and the Church's institutional concealment of such facts, the researcher may encounter great difficulties in finding testimonies and documents other than those publicized by the media. Nevertheless, they can analyze the strategic function of the overt layer of the discourse on pedophilia in the Church and of the non-discursive practices which accompany it. Here, it would be useful to identify the modernizing and (anti)Westernizing practices as well as those connected with dignity and settling accounts, and whether their role is controlling the discussion over whether the moral power of the Catholic Church is a premodern relic blocking the Polish axiological modernization and confirming its peripheral place on Europe's map, or, perhaps, whether this power is proof of the Polish Church's autocephaly and the deepening social and cultural gap between Poland and other European countries.

It might seem that the issue of pedophilia among the clergy and the reactions to it have little to do with the category of neoliberal governmentality. However, pastoral power has, according to Foucault, a protoliberal character, as it individualizes people, making them moral subjects. In contemporary Poland, the Church's power extends over political and economic areas (the Church enjoys tax exemptions and some of the clergy run businesses), so it is, to an extent, subject to the post-transformation market rationality. Most importantly, the Church promotes a particular model of a moral subject, one preferably involved in defending the Catholic morality against external influence. Nowadays, the Church rarely excludes its members for departure from its doctrine, provided they do not question its mandate to pastoral power. It is, therefore, not a case of liberalism in the sense of an emancipatory philosophy (of which hierarchs of the Catholic Church in Poland speak in negative and discrediting terms), nor of economic neoliberalism, but, rather, of a pact with the faithful, normalizing their behavior rather than absolutely disciplining them, for the price of the latter ones' obedience toward the institution of the Church.

In the context of pedophilia, which in the European (including Polish) culture is perceived as one of the most serious and unforgivable crimes, the expected results of disclosing cases of sexual violence toward children are wavering of religious attitudes in the Polish society and the loss of a significant number of churchgoing Poles from attending religious practices within the institution. However, the purpose of the dispositif reacting to pedophilia is to neutralize and curb the tendency to reject the moral power of the Catholic Church. The question for the researcher is one about the techniques of this limiting and their practical effects, if possible, based on quantitative data concerning attitudes toward the Church, its religious practice, and qualitative data gathered among Catholics, e.g. through free interviews. Since the subject of analysis is an institution enjoying great authority in the society and a high cultural and political position, the research must include not only the contemporary dimension of how the pastoral power of the Catholic Church in Poland functions, but also the analysis of symbolic resources used to defend/criticize the Church in their historical and diachronic contexts while taking into account how these resonate with Polish cultural texts problematizing the Church's influence on shaping the Polish identity and subjectivity (Augustyniak 2019). Based on the critical juxtaposition of the above-mentioned types of data, one can draw conclusions concerning the continuity or lack thereof with regard to the formation of moral subjects in post-socialist Poland, who 
on the one hand aspire to the secular standards of social life copied from the West, while on the other hand they cultivate power networks which have lost their importance in countries of the European Center.

\section{Conclusion}

The present article had two purposes. The first one was to show the critical and interdisciplinary potential of the post-Foucauldian dispositif analysis. The second one was to present a proposition for a research program adjusting this approach to studies of power relations in post-socialist societies of Eastern Europe, which is based on using the interdisciplinary possibilities of dispositif analysis. The proposed approach is undoubtedly dominated by the sociological perspective. The examples of research problems are also mainly sociological and the recommendation to make dispositif analysis more interdisciplinary assumes a certain lack of symmetry of terms and methods taken from different disciplines of knowledge, i.e. the sociologist's research tools are complemented by inspirations from other disciplines, but not vice versa. Despite this, in the case of research carried out in the context of Eastern Europe, I would suggest a rather broad acceptance of the achievements of disciplines such as linguistics, cultural studies, media studies, literary studies, economy, political sciences, psychology, and even psychoanalysis or religious studies. This is not a complete list, nor is it one that should be fully implemented with reference to the specific areas subject to analysis.

Applying the post-Foucauldian perspective in empirical research on Eastern Europe is in itself a bold transgression of Foucault's oeuvre as well as a conceptual and methodological challenge. An attempt at overcoming this challenge requires critical reflection on the Foucauldian lexicon and proposing errata corresponding to the local research context. What is helpful here is referencing other disciplines and methods of analysis as long as it is possible to find in them a common approach which would be key to analyzing the dispositif of the phenomenon of power. The cost of this interdisciplinarity will probably be a reduced clarity of the independent nature of the post-Foucauldian approach, but the gain might come in the form of actual empiricization of this theoretically-sublimated perspective. Dispositif analysis seems predestined to take on such a methodological and intellectual challenge.

\section{References}

Alvargonzález, David. 2011. "Multidisciplinarity, Interdisciplinarity, Transdisciplinarity, and the Sciences." International Studies in the Philosophy of Science 25(4):387-403.

Amaral, Luiz Guilherme Leite. 2016. The Church According to Foucault's Concept of Apparatus, in Portuguese at INTERCOM Estudos Interdisciplinares da Comunicação do XXI Congresso de
Ciências da Comunicação na Região Sudeste. Retrevied March 16, 2019 (https://www.academia.edu/32558718/The_Church_According_to_Foucaults_Concept_of_Apparatus).

Angermuller, Johannes. 2010. “Widerspenstiger Sinn. Skizze eines diskursanalytischen Forschungsprogramms nach dem Strukturalismus." Pp. 71-100 in Diskursanalyse meets Gouverne- 
mentalitätsforschung. Perspektiven auch das Verhältniss von Subjekt, Sprache, Macht und Wissen, edited by Johannes Angermuller and Silke van Dyk. Frankfurt am Main, New York: Campus.

Augustyniak, Piotr. 2015. Homo polacus: Eseje o polskiej duszy. Cracow: Znak.

Augustyniak, Piotr. 2019. Wyspiański: Burzenie polskiego kościoła. Studium o "Wyzwoleniu." Cracow: Znak.

Barthes, Roland. 1972. Mythologies. New York: Hill and Wang.

Blanchet, Thomas, Lucas Chancel, and Amory Gethin. 2019. "How unequal is Europe? Evidence from Distributional National Accounts, 1980-2017". WID.world WORKING PAPER, 6. Retrieved October 15, 2020 (https://wid.world/document/ bcg2019-full-paper/).

Bourdieu, Pierre. 1986. "The Forms of Capital." Pp. 241-58 in Handbook of Theory and Research for Sociology of Education, edited by J. G. Richardson. New York, London: Greenwood Press.

Buden, Boris. 2010. “Children of Postcommunism." Radical Philosophy 159:18-25.

Bugaj, Ryszard. 2015. Plusy dodatnie i ujemne, czyli polski kapitalizm bez solidarności. Warsaw: Poltext.

Bührmann, Andrea D. 2004. "Das Auftauchen des unternehmerischen Selbst und seine gegenwärtige Hegemonialität. Einige grundlegende Anmerkungen zur Analyse des (Trans) Formierungsgeschehens moderner Subjektivierungsweisen." Forum Qualitative Sozialforschung 6(1). Retrieved August 7, 2019 (http://nbn-resolving.de/urn:nbn:de:0114-fqs0501165).

Bührmann, Andrea D., and Werner Schneider. 2008. Vom Diskurs zum Dispositiv. Eine Einführung in die Dispositivanalyse. Bielefeld: transcript.

Choi, Bernard C. K. and Anita W. P. Pak. 2006. "Multidisciplinarity, Interdisciplinarity and Transdisciplinarity in Health Research, Services, Education and Policy: 1. Definitions, Objectives, and Evidence of Effectiveness." Clinical and Investigative Medicine 29:351-364.

Chutorański, Maksymilian. 2015. “Urządzenie (edukacyjne): sieci, dyskursy, ludzie, nie-ludzie." Teraźniejszość - Człowiek Edukacja 18(4):7-21.

Cruikshank, Barbara. 1999. The Will to Empower. Democratic Citizens and Other Subjects. Ithaca: Cornell University Press.
Czyżewski, Marek. 2012. Wiedza specjalistyczna i praktyka społeczna-przemiany i pułapki. Pp. 71-93 in Kontrowersje dyskursywne. Między wiedza specjalistyczna a praktyka społeczna, edited by Arkadiusz Jabłoński, Jan Szymczyk, and Mariusz Zemło. Lublin: Wydawnictwo KUL.

Czyżewski, Marek et al. 2017. “Wprowadzenie." Pp. 9-25 in Analiza dyskursu publicznego. Przeglad metod i perspektyw badawczych, edited by Marek Czyżewski et al. Warsaw: Sedno.

Dean, Mitchell. 2018. "Foucault and the Neoliberalism Controversy." Pp. 40-53 in The SAGE Handbook of Neoliberalism, edited by Damien Cahill et al. London: SAGE Publications.

Diaz-Bone, Rainer. 2007. “Die französische Epistemologie und ihre Revisionen. Zur Rekonstruktion des methodologischen Standortes der Foucaultschen Diskursanalyse." Forum Qualitative Sozialforschung 8(2). Retrieved September 7, 2019 (http:// nbnresolving.de/urn:nbn:de:0114-fqs0702241).

Ditrych, Ondřej. 2011. "The Dispositif of "Eastern Neighborhood": A Framework for Analysis." Pp. 27-34 in The Scale of Globalization. Think Globally, Act Locally, Change Individually in the 21st Century, edited by Přemysl Mácha, and Tomáš Drobík. Ostrava: University of Ostrava. Retrieved December 27, 2019 (http://conference.osu.eu/globalization/publ2011/27-34_Ditrych.pdf).

Ditrych, Ondřej. 2014. Tracing the Discourses of Terrorism: Identity, Genealogy and State. New York: Palgrave Macmillan.

Eco, Umberto, and Thomas A. Sebeok, eds. 1984. The Sign of Three: Dupin, Holmes, Peirce. Bloomington: Indiana University Press.

Eyal, Gil, Ivan Szelenyi, and Eleanor R. Townsley. 2001. Making Capitalism Without Capitalists: The New Ruling Elites in Eastern Europe. London, New York: Verso.

Florence, Maurice. 1988. “(Auto)biography: Michel Foucault 1926-1984." History of the Present 4:13-15.

Foucault, Michel. 1978. The History of Sexuality. Volume I: An Introduction. New York: Pantheon Books.

Foucault, Michel. 1980. “The Confession of the Flesh.” Pp. 194228 in Power/ Knowledge: Selected Interviews \& Other Writings 1972-1977 by Michel Foucault, edited by Colin Gordon. New York: Pantheon Books.

Foucault, Michel. 2000. “The Subject and Power." Pp. 326-348 in Power, edited by James D. Faubion. New York: New York Press. 
Foucault, Michel. 2008. The Birth of Biopolitics: Lectures at the Collège de France 1978-1979. London: Palgrave.

Foucault, Michel. 2018. Histoire de la sexualité IV: Les aveux de la chair. Paris: Gallimard.

Foucault, Michel and Paolo Caruso. 1999. "Who Are You, Professor Foucault?" Pp. 87-103 in Religion and Culture, edited by Jeremy R. Carrette. New York: Routledge.

Gomułka, Stanisław. 1985. "Kornai's Soft Budget Constraint and the Shortage Phenomenon: A Criticism and Restatement." Economics of Planning 19(1):1-11.

Hamann, Julian et al. 2019. "The Academic Dispositif: Towards a Context-Centred Discourse Analysis." Pp. 57-81 in Quantifying Approaches to Discourse for Social Scientists. Postdisciplinary Studies in Discourse, edited by Ronny Scholz. Cham: Palgrave Macmillan.

Hoffarth, Britta. 2013. "Schmutzige Witze. Erkundung eines Bildungsereignisses im Geschlechter-Dispositiv." Pp. 91-110 in Verortungen des Dispositiv-Begriffs. Analytische Einsätze zu Raum, Bildung, Politik, edited by Joannah Caborn Wengler, Britta Hoffarth, and Łukasz Kumięga. Wiesbaden: Springer VS.

Hušek, Petr and Kateřina Tvrdá. 2016. “The Collective Singularity of Anti-Racist Actors: A Case Study of the Roma Minority in the Czech Republic." Ethnic and Racial Studies 39(1):49-67.

Jäger, Siegfried. 2012. Kritische Diskursanalyse. Eine Einführung. Duisburg: Edition DISS.

Keller, Reiner. 1998. Müll. Die gesellschaftliche Konstruktion des Wertwollen. Opladen: Westdeutscher Verlag.

Keller, Reiner. 2005. Wissenssoziologische Diskursanalyse. Grundlegung eines Forschungsprogramms. Wiesbaden: VS Verlag.

Keller, Reiner. 2007. “Diskurse und Dispositif analysieren. Die Wissenssoziologische Diskursanalyse als Beitrag zu einer wissensanalytischen Profilierung der Diskursforschung." Forum Qualitative Sozialforschung 2(8). Retrieved December 7, 2019 (http://nbn-resolving.de/urn:nbn:de:0114-fqs0702198).

Kideckel, David. 2014. "Post-socialism as Uncertainty, Uncertainty about Post-socialism." Pp. 15-26 in Does East Go West?: Anthropological Pathways Through Postsocialism, edited by Christian Giordano, Francois Ruegg, and Andrea Boscoboinik. Berlin: LIT Verlag.
Kornai, János. 1980. Economics of Shortage. Amsterdam: North-Holland Pub. Co.

Kovacs, János M. 1992. Reform and Transformation. Eastern European Economics on the Threshold of Change. London: Routledge.

Krasnodębski, Zdzisław. 2003. Demokracja peryferii. Gdansk: słowo/obraz terytoria.

Kubala, Konrad. 2019. Racjonalność w dyskursach o pracy w Polsce (po) transformacyjnej. Lodz: Wydawnictwo Uniwersytetu Łódzkiego.

Kumięga, Łukasz. 2013. Rechtsextremistischer Straßendiskurs in Deutschland. Frankfurt am Main: Peter Lang Verlag.

Lakatos, Imre. 1968. "Criticism and the Methodology of Scientific Research Programmes." Proceedings of the Aristotelian Society 69:149-186.

Lakatos, Imre. 1999. "Lecture 8: The Methodology of Scientific Research Programmes." Pp. 96-108 in For and Against Method, edited by Matteo Motterlini. Chicago, IL: University of Chicago Press.

Leder, Andrzej. 2014. Prześniona rewolucja: Ćwiczenia z logiki historycznej. Warsaw: Wydawnictwo Krytyki Politycznej.

Lubaś, Marcin. 2017. “Sprzężenia krytyczne: antropologia, postsocjalizm, postkolonialność. Słowo wstępne." Zeszyty Naukowe Uniwersytetu Jagiellońskiego. Prace Etnograficzne 45(4):VII-XX.

Lyubenova, Rositsa. 2017. "Socialist Family as a Biopolitical Dispositif." Pp. 123-134 in The New Diversity of Family Life in Europe: Mobile Ethnic Groups and Flexible Boundaries, edited by Banu Çitlak et al. Springer: Wiesbaden.

Łuczeczko, Paweł. 2012. “Antropologia współczesności w Polsce: narodziny, rozwój, perspektywy." Rocznik Antropologii Historii 2(1):21-45.

Maesse, Jens. 2017. “The Elitism Dispositif: Hierarchization, Discourses of Excellence and Organizational Change in European Economics." Higher Education 73: 909-927.

Marttila, Tomas. 2015. "Post-Foundational Discourse Analysis: A Suggestion for a Research Program." Forum Qualitative Sozialforschung 16(3). Retrieved December 7, 2019 (http://nbn-resolving.de/urn:nbn:de:0114-fqs150319).

Mitterhofer, Hermann. 2016. Das Repräsentations-Dispositiv. Paderborn: Wilhelm Fink. 
Mraović, Boriša. 2018. Heroism of Labor: The Anti-Fascist Front of Women and the Socialist Dispositif 1945-1953. Retrieved August 5, 2019 (viewpointmag.com/2018/09/30/heroism-of-laborthe-anti-fascist-front-of-women-and-the-socialist-dispositif-1945-1953/).

Napiórkowski, Marcin. 2018. Mitologia wspótczesności. Warsaw: Wydawnictwo Naukowe PWN.

Niediek, Imke. 2010. Das Subjekt im Hilfesystem. Eine Studie zur Individuellen Hilfeplanung im Unterstützten Wohnen für Menschen mit einer geistigen Behinderung. Wiesbaden: VS Verlag.

Nowicka-Franczak, Magdalena. 2017. Niechciana debata. Spór o książki Jana Tomasza Grossa. Warsaw: Sedno.

Nowicka-Franczak, Magdalena. in print. "Post-Foucauldian Discourse and Dispositif Analysis in the Post-Socialist Field of Research: Methodological Remarks." Qualitative Sociology Review 17(1).

Ostrowicka, Helena. 2015. Przemyśleć z Michelem Foucaultem edukacyjne dyskursy o młodzieży: Dyspozytyw i urzadzanie. Cracow: Impuls.

Ostrowicka, Helena. 2016. "Apetyt na wiedzę? O perspektywie badania konsumpcjonizmu poznawczego." Parezja 1:26-41.

Ostrowicka, Helena. 2019. Regulating Social Life: Discourses on the Youth and the Dispositif of Age. Cham: Palgrave Macmillan.

Ostrowicka, Helena, Justyna Spychalska-Stasiak, and Łukasz Stankiewicz. 2020. The Dispositif of the University Reform: Higher Education Policy Discourse in Poland. New York: Routledge.

Paulus, Stefan. 2015. "Methodologische Uberlegungen und methodisches Vorgehen bei einer intersektionalen Dispositivanalyse." Forum Qualitative Sozialforschung 16(1). Retrieved December 7, 2019 (http://nbn-resolving.de/urn:nbn:de:0114fqs1501210).

Peeters, Hugues and Philippe Charlier. 1999. "Contributions à une théorie du dispositif." Hermès 25:15-23.

Pezelj, Andrej. 2015. "Painting According to Foucault, in Spite of Foucault: The Pastoral Origins of Contemporary Art." Pp. 240-251 in Engaging Foucault, vol. 2, edited by Marjan Ivković, Gazela Pudar Draško, and Srđan Prodanović. Belgrade: University of Belgrade, Institute for Philosophy and Social Theory.
Porter-Szücs, Brian. 2011. Faith and Fatherland: Catholicism, Modernity, and Poland. New York: Oxford University Press.

Profant, Tomáš. 2018. "The Social Construction of Slovakia as a Donor and its Power Effects." Europe-Asia Studies 70(3):365-387.

Rabinow, Paul and Anthony Stavrianakis. 2013. Demands of the Day: On the Logic of Anthropological Inquiry. Chicago: University of Chicago Press.

Raffnsøe, Sverre, Marius Gudmand-Høyer, and Morten S. Thaning. 2011. Foucault. Munich: Wilhelm Fink.

Raffnsøe, Sverre, Marius Gudmand-Høyer, and Morten S. Thaning. 2016. "Foucault's Dispositif: The Perspicacity of Dispositif Analytics in Organizational Research." Organization 23(2):272-298.

Ricken, Norbert. 2015. "Bildung als Dispositiv: Bemerkungen zur (Macht-)Logik eines Subjektivierungsmusters." Pp. 4158, in Medien - Bildung - Dispositive: Beiträge zu einer interdisziplinären Medienbildungsforschung, edited by J. Othmer and Andreas Weich. Wiesbaden: Springer VS.

Ritzer, George and Nathan Jurgenson. 2010. "Production, Consumption, Prosumption." Journal of Consumer Culture 10(1):13-36.

Rose, Nadine. 2013. “Gebildete Körper - Verkörperte Ordnungen. Subjektivierungen im Ausländer-Dispositiv." Pp. 111-128 in Verortungen des Dispositiv-Begriffs. Analytische Einsätze zu Raum, Bildung, Politik, edited by Joannah Caborn Wengler, Britta Hoffarth, and Łukasz Kumięga. Wiesbaden: Springer VS.

Schmidt, Jan C. 2008. "Towards a Philosophy of Interdisciplinarity: An Attempt to Provide a Classification and Clarification." Praxis and Poiesis 5:53-71.

Sulima, Roch. 2000. Antropologia codzienności. Cracow: Wydawnictwo Uniwersytetu Jagiellońskiego.

Thelen, Tatjana. 2011. "Shortage, Fuzzy Property and other Dead Ends in the Anthropological Analysis of (Post)socialism." Critique of Anthropology 31(1):43-61.

Toader, Florenta. 2014. "Politics and Leadership on Facebook during the 2012 Romanian Parliamentary Elections and the 2014 Euro-parliamentary Elections." Management Dynamics in the Knowledge Economy 2(2):399-419.

Toader, Florenta. 2017. “Discursive Strategies Used by Romanian Politicians in the Context of the Refugee Crisis." Pp. 269- 
288 in Why Europe? Narratives and Counter-narratives of European Integration, edited by Alina Bârgaoanu, Raluca Buturoiu, and Loredana Radu. Berlin: Peter Lang Academic Research.

Truschkat, Inga. 2008. Kompetenzdiskurs und Bewerbungsgespräche-Eine Dispositivanalyse (neuer) Rationalitäten sozialer Differenzierung. Wiesbaden: VS Verlag.

Wallerstein, Immanuel. 1974. The Modern World-System. New York: Academic Press.

Warczok, Tomasz and Tomasz Zarycki. 2014. “Bourdieu Recontextualized: Redefinitions of Western Critical Thought in the Periphery." Current Sociology 62(3):334-351.
Wasilewski, Jacek. 2012 Opowieści o Polsce: Retoryka narracji. Warsaw: Headmade.

Wnuk-Lipiński, Edmund. 1996. Demokratyczna rekonstrukcja. $Z$ socjologii radykalnej zmiany ustrojowej. Warsaw: Wydawnictwo Naukowe PWN.

Zamora, Daniel and Michael C. Behrent, eds. 2016. Foucault and Neoliberalism. Cambridge: Polity Press.

Zarycki, Tomasz. 2014. “Innowacjonizm jako legitymizacja. Dyskursy innowacji, gospodarki opartej na wiedzy, społeczeństwa informacyjnego i pokrewne w perspektywie krytycznej." Zarzadzanie Publiczne 1(27):20-34.

\section{Citation}

Nowicka-Franczak, Magdalena. 2020. “Dispositif Analysis in Eastern Europe: The Outline of a Research Program.” Przeglad Socjologii Jakościowej 16(4):146-169. Retrieved Month, Year (www.przegladsocjologiijakosciowej.org). DOI: http://dx.doi.org/10.18778/17338069.16.4.08

\section{Analiza dyspozytywu w Europie Wschodniej: zarys programu badawczego}

Abstrakt: Artykuł dotyczy zastosowań analizy dyspozytywu, inspirowanej przez późne prace Michela Foucaulta, w innym kontekście niż oryginalny. Autorka prezentuje główne założenia metodologiczne analizy dyspozytywu oraz czynniki, które blokują pełne wykorzystanie jej krytycznego i interdyscyplinarnego potencjału. Na podstawie przeglądu dorobku analizy dyspozytywu w postsocjalistycznej Europie Wschodniej autorka formułuje propozycję interdyscyplinarnego programu badawczego. Jego celem jest zaadaptowanie tego podejścia do badań wschodnioeuropejskich siatek władzy przy uwzględnieniu zarówno innego kontekstu historycznego, kulturowego i geopolitycznego niż w krajach Europy Zachodniej, jak i specyficznego postrzegania neoliberalizmu u Foucaulta. Rekomendacje metodologiczne są przedstawione na przykładzie dwóch obszarów badań: 1) pracy w polskim społeczeństwie potransformacyjnym i 2) reakcji na pedofilię w polskim Kościele katolickim.

Słowa kluczowe: analiza dyspozytywu, Europa Wschodnia, interdyscyplinarność, neoliberalizm, Polska 